\title{
Russian Nesting Doll Complexes of Molecular Baskets and Zinc Containing TPA Ligands
}

Lei Zhiquan, Shane Polen, Christopher M. Hadad, T. V. RajanBabu and Jovica D. Badjić*

Department of Chemistry and Biochemistry, The Ohio State University, 100 West 18th Avenue, Columbus, OH 43210

E-mail: badjic.1@osu.edu 


\section{Contents}

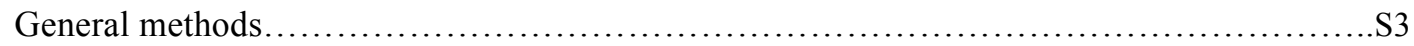

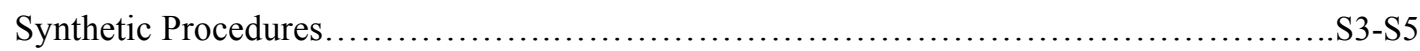

${ }^{1}$ H NMR spectra, ITC and ESI-MS characterizations........................................S6-S19

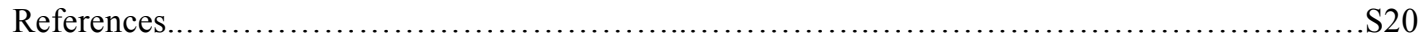




\section{General Methods}

All solvents were dried before use following standard procedures. Unless indicated otherwise, all starting materials were obtained from commercial suppliers and used without additional purification. Analytical thin-layer chromatography (TLC) was performed on silica-gel plates w/UV254. ${ }^{1} \mathrm{H}$ NMR and ${ }^{13} \mathrm{C}$ NMR spectra were recorded on 400,600 or $700 \mathrm{MHz}$ spectrophotometers. Chemical shifts are expressed in parts per million $(\delta, \mathrm{ppm})$ using residual solvent protons as an internal standard; for calibrating ${ }^{1} \mathrm{H}$ NMR spectra we used $\mathrm{CDCl}_{3}=7.259 \mathrm{ppm}, \mathrm{CD}_{3} \mathrm{OD}=3.31 \mathrm{ppm}$ and $\mathrm{D}_{2} \mathrm{O}=4.79 \mathrm{ppm}$ while for ${ }^{13} \mathrm{C}$ NMR spectra $\mathrm{CDCl}_{3}=77.0 \mathrm{ppm}$ and $\mathrm{CD}_{3} \mathrm{OD}=49.0 \mathrm{ppm}$. The measurements of $\mathrm{pH}$ were completed with HI 2210 pH meter. Circular dichroism (CD) spectra were measured with JASCO-815 spectrometer. UV-Vis measurements were completed with Shimadzu CARY-100 spectrophotometer.

\section{Synthetic Procedures}

Compound 5 was prepared by following literature procedures ${ }^{1}$ and from commercially available 6-methylnicotonate $4 ;{ }^{1} \mathrm{H}$ NMR data corresponding to 5 is in line with the literature. ${ }^{1}$

Compound 6: ${ }^{2}$ To compound 5 (10 mmol, $\left.2.3 \mathrm{~g}\right)$, dissolved in dry dimethyl formamide $(50 \mathrm{~mL})$ and under an atmosphere of nitrogen, $\mathrm{NH}_{4} \mathrm{Br}(3.33 \mathrm{mmol}, 326.1 \mathrm{mg})$ and $\mathrm{Na}_{2} \mathrm{CO}_{3}(20$ mmol, $1.68 \mathrm{~g})$ were added. The reaction mixture was sealed and stirred at room temperature for 5 days, followed by heating at $60{ }^{\circ} \mathrm{C}$ for 8 hours. Subsequently, the mixture was poured into water $(100 \mathrm{~mL})$ and extracted with

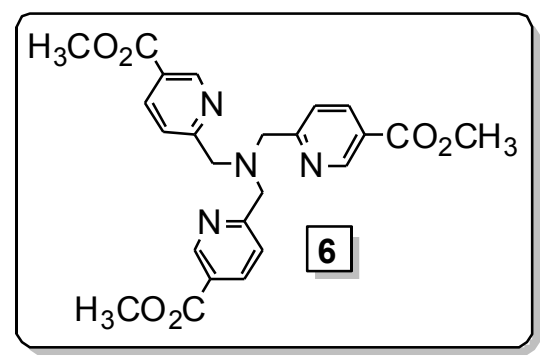
dichloromethane $(3 \times 50 \mathrm{~mL})$. The combined organic layers were washed with saturated $\mathrm{NaCl}$ solution ( 3 x $20 \mathrm{~mL}$ ). Upon removal of the organic solvent in vacuum, compound 6 was purified by column chromatography $\left(\mathrm{SiO}_{2}\right.$, acetone:hexane:ethylacetate $\left.=1: 4: 5\right)$ and recrystallized from ethylacetate/hexane $=1: 2$ to give light yellow solid $(1.084 \mathrm{~g}, 70 \%) .{ }^{1} \mathrm{H} \mathrm{NMR}\left(600 \mathrm{MHz}, \mathrm{CDCl}_{3}\right) \delta$ (ppm): 9.13 (dd, $J=2.4,0.6 \mathrm{~Hz}, 1 \mathrm{H}), 8.25$ (dd, $J=8.4,1.8 \mathrm{~Hz}, 1 \mathrm{H}), 7.63$ (d, $J=8.4 \mathrm{~Hz}, 1 \mathrm{H}), 3.96$ (s, 2H), $3.94(\mathrm{~s}, 3 \mathrm{H}) .{ }^{13} \mathrm{C}$ NMR (150 MHz, $\left.\mathrm{CDCl}_{3}\right) \delta(\mathrm{ppm}): 165.72,163.41,150.48,137.58,124.66$, 122.54, 60.09, 52.34. HRMS (ESI): $m / z$ : $[\mathrm{M}+\mathrm{H}]^{+}$calculated for $\mathrm{C}_{24} \mathrm{H}_{25} \mathrm{~N}_{4} \mathrm{O}_{6}$ : 465.17686, found 465.17689 .

Compound $7:{ }^{3}$ To compound $6(2 \mathrm{mmol}, 0.928 \mathrm{~g})$ dissolved in dry tetrahydrofuran $(40 \mathrm{~mL})$ and at room temperature, $\mathrm{LiBH}_{4}(12 \mathrm{mmol}, 261.6 \mathrm{mg})$ was added in portions over 2 days. After stirring for an additional day, the reaction mixture was heated to reflux for 8 hours. The solvent was removed under reduced pressure, and crude product purified by column chromatography $\left(\mathrm{SiO}_{2}\right.$, methanol:dichloromethane:aqueous ammonia $=1 / 3 / 0.05)$ to give 7 as a yellow solid (532.6 mg, 70\%). ${ }^{1} \mathrm{H} \mathrm{NMR} \mathrm{(600} \mathrm{MHz,}$

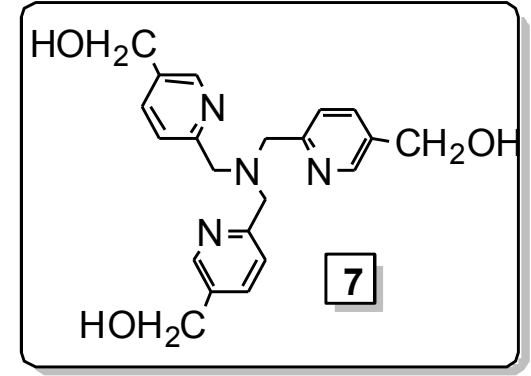


$\left.\mathrm{CD}_{3} \mathrm{OD}\right) \delta(\mathrm{ppm}): 8.42(\mathrm{~d}, J=1.8 \mathrm{~Hz}, 1 \mathrm{H}), 7.77(\mathrm{dd}, J=8.4,2.1 \mathrm{~Hz}, 1 \mathrm{H}), 7.61(\mathrm{~d}, J=8.4 \mathrm{~Hz}, 1 \mathrm{H})$, $4.62(\mathrm{~s}, 2 \mathrm{H}), 3.85(\mathrm{~s}, 2 \mathrm{H}) .{ }^{13} \mathrm{C} \mathrm{NMR}\left(150 \mathrm{MHz}, \mathrm{CD}_{3} \mathrm{OD}\right) \delta(\mathrm{ppm}): 158.87,148.21,137.50,137.45$, 124.62, 62.37, 60.89. HRMS (ESI): $m / z:[\mathrm{M}+\mathrm{H}]^{+}$calculated for $\mathrm{C}_{21} \mathrm{H}_{25} \mathrm{~N}_{4} \mathrm{O}_{3}$ : 381.19212 , found 381.19219.

Compound 8: ${ }^{4}$ To neat $\mathrm{SOCl}_{2}(5.08 \mathrm{~mL}, 70 \mathrm{mmol})$ kept at $0{ }^{\circ} \mathrm{C}$, compound 7 (532.6 mg, $\left.1.4 \mathrm{mmol}\right)$ was added and the reaction mixture stirred at room temperature for 12 hours. The solvent was removed under reduced pressure and crude product was dissolved in anhydrous dimethyl formamide $(40 \mathrm{~mL})$ to which we added $\mathrm{NaI}$ (1.26 g, $8.4 \mathrm{mmol}$ ), $\mathrm{NaN}_{3}(546 \mathrm{mg}, 8.4 \mathrm{mmol}$ ) and $\mathrm{NaHCO}_{3}(1.176 \mathrm{~g}, 14 \mathrm{mmol})$. The reaction mixture was stirred at $60{ }^{\circ} \mathrm{C}$ for 12 hours and under an atmosphere of nitrogen. Subsequently, the reaction mixture was quenched with water

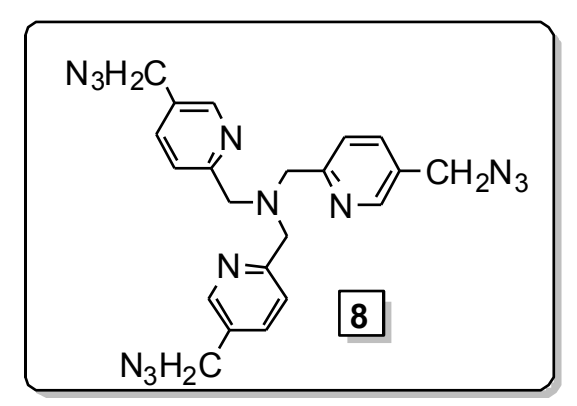
$(70 \mathrm{~mL})$ and extracted by ethyl acetate $(3 \times 100 \mathrm{ml})$. The combined organic phases were washed with saturated $\mathrm{NaCl}$ solution $(3 \times 15 \mathrm{~mL})$ and dried with $\mathrm{Na}_{2} \mathrm{SO}_{4}$. Upon removal of the solvent in vacuum, the crude product was purified by column chromatography $\left(\mathrm{SiO}_{2}\right.$, dichloromethane $/$ methanol/hexanes $=$ 15:1:10) to give 7 as a yellow solid (522.9 mg, two steps $82 \%)$. ${ }^{1} \mathrm{H}$ NMR (600 MHz, $\left.\mathrm{CDCl}_{3}\right) \delta(\mathrm{ppm})$ : $8.47(\mathrm{~d}, J=1.8 \mathrm{~Hz}, 1 \mathrm{H}), 7.61(\mathrm{dd}, J=7.8,2.4 \mathrm{~Hz}, 1 \mathrm{H}), 7.55(\mathrm{~d}, J=8.4 \mathrm{~Hz}, 1 \mathrm{H}), 4.34$ (s, 2H), $3.92(\mathrm{~s}$, 2H). ${ }^{13} \mathrm{C}$ NMR (150 MHz, $\left.\mathrm{CDCl}_{3}\right) \delta(\mathrm{ppm}):$ 159.32, 148.62, 136.24, 129.45, 123.04, 59.93, 51.90. HRMS (ESI): $m / z$ : $[\mathrm{M}+\mathrm{H}]^{+}$calculated for $\mathrm{C}_{21} \mathrm{H}_{22} \mathrm{~N}_{13}: 456.21156$, found 456.21164.

Compound 1: ${ }^{2}$ To a solution of compound $8(45 \mathrm{mg}, 0.1 \mathrm{mmol})$ in tetrahydrofuran $(4.8 \mathrm{~mL})$ was added triphenylphosphine $(131 \mathrm{mg}, 0.5 \mathrm{mmol})$ and water $(0.3 \mathrm{~mL})$. The reaction mixture was stirred at $50{ }^{\circ} \mathrm{C}$ for 12 hours. The solvent was removed under reduced pressure, and the residue dissolved in water $(10 \mathrm{~mL})$. The $\mathrm{pH}$ of the aqueous solution was adjusted to 1 with $2 \mathrm{M} \mathrm{HCl}$ and then extracted with $\mathrm{CH}_{2} \mathrm{Cl}_{2}(10 \mathrm{~mL})$, which was discarded. The aqueous layer was subsequently removed under reduced pressure and the remaining solid dissolved in methanol $(10 \mathrm{~mL})$. Basic ion-exchange resin (Amberlyst A26, OH-form; $300 \mathrm{mg}$ ) was added to this methanol

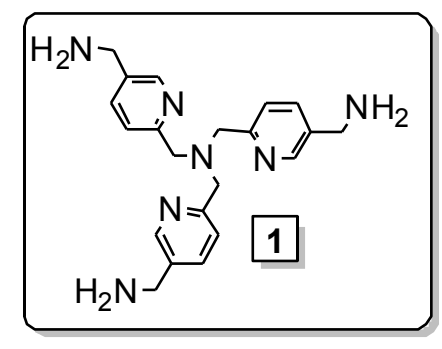
solution of the product. After 3 hours of stirring, we filtered and washed the residue with methanol (20 $\mathrm{mL})$. The combined organic solvents were removed under reduced pressure to give $\mathbf{1}$ as a yellow solid (67.9 mg, 90\%). ${ }^{1} \mathrm{H}$ NMR (600 MHz, $\left.\mathrm{CD}_{3} \mathrm{OD}\right) \delta(\mathrm{ppm}): 8.41$ (d, $\left.J=1.2 \mathrm{~Hz}, 1 \mathrm{H}\right), 7.79$ (dd, $J=7.8,2.4$ $\mathrm{Hz}, 1 \mathrm{H}), 7.63(\mathrm{~d}, J=7.8 \mathrm{~Hz}, 1 \mathrm{H}), 3.81(\mathrm{~s}, 2 \mathrm{H}), 3.80(\mathrm{~s}, 2 \mathrm{H}) .{ }^{13} \mathrm{C} \mathrm{NMR}\left(150 \mathrm{MHz}, \mathrm{CD}_{3} \mathrm{OD}\right) \delta(\mathrm{ppm}):$ 158.60, 148.81, 138.40, 137.87, 124.59, 60.71, 43.80. HRMS (ESI): $m / z:[\mathrm{M}+\mathrm{H}]^{+}$calculated for $\mathrm{C}_{21} \mathrm{H}_{28} \mathrm{~N}_{7}: 378.24007$, found 378.24025. 
<smiles>OCc1ccccn1</smiles><smiles>[13CH3][13CH3]</smiles><smiles>BrCc1ccccn1</smiles>
$\mathrm{HBr}$

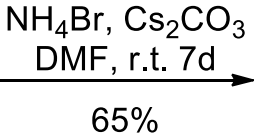

$65 \%$<smiles>c1ccc(CN(Cc2ccccn2)Cc2ccccn2)nc1</smiles>

TPA

9

TPA ligand: An aqueous solution of $\operatorname{HBr}(69 \%, 10 \mathrm{~mL}$ ) was added to compound 9 (327.3 mg, 3 $\mathrm{mmol})$ and the reaction mixture heated at reflux for 12 hours. The solvent was removed under reduced pressure and crude product dissolved in anhydrous dimethyl formamide $(15 \mathrm{~mL})$. To this solution, $\mathrm{NH}_{4} \mathrm{Br}(98 \mathrm{mg}, 1 \mathrm{mmol})$ and $\mathrm{Cs}_{2} \mathrm{CO}_{3}(977.4 \mathrm{mg}, 3 \mathrm{mmol})$ were added and the reaction mixture was sealed and stirred at room temperature for seven days. The mixture was transferred to water $(30 \mathrm{~mL})$, extracted with dichloromethane $(3 \times 60 \mathrm{~mL})$ and combined organic layers washed with saturated $\mathrm{NaCl}$ solution $(3 \times$ x $20 \mathrm{~mL})$. Crude TPA was purified with column chromatography $\left(\mathrm{SiO}_{2}\right.$, acetone:hexanes:ethylacetate $=1: 5: 3)$ and then recrystallized from ethylacetate:hexanes $=1: 1$ to give TPA as a light yellow solid $(188.5 \mathrm{mg}, 65 \%) .{ }^{1} \mathrm{H}$ NMR spectrum of TPA is in agreement with the literature. ${ }^{5}{ }^{1} \mathrm{H}$ NMR $\left(600 \mathrm{MHz}, \mathrm{CDCl}_{3}\right) \delta(\mathrm{ppm}): 8.54-8.53(\mathrm{~m}, 1 \mathrm{H}), 7.65(\mathrm{td}, J=7.8,1.8 \mathrm{~Hz}, 1 \mathrm{H}), 7.58$ (d, $J=7.8 \mathrm{~Hz}, 1 \mathrm{H}), 7.14$ (ddd, $J=7.2,4.8,1.2 \mathrm{~Hz}, 1 \mathrm{H}), 3.89$ (s, 2H). 


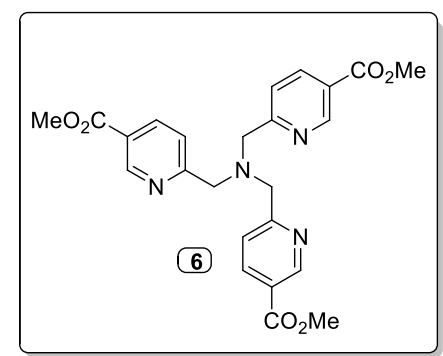

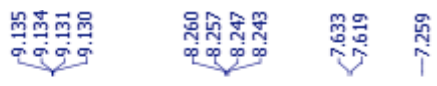

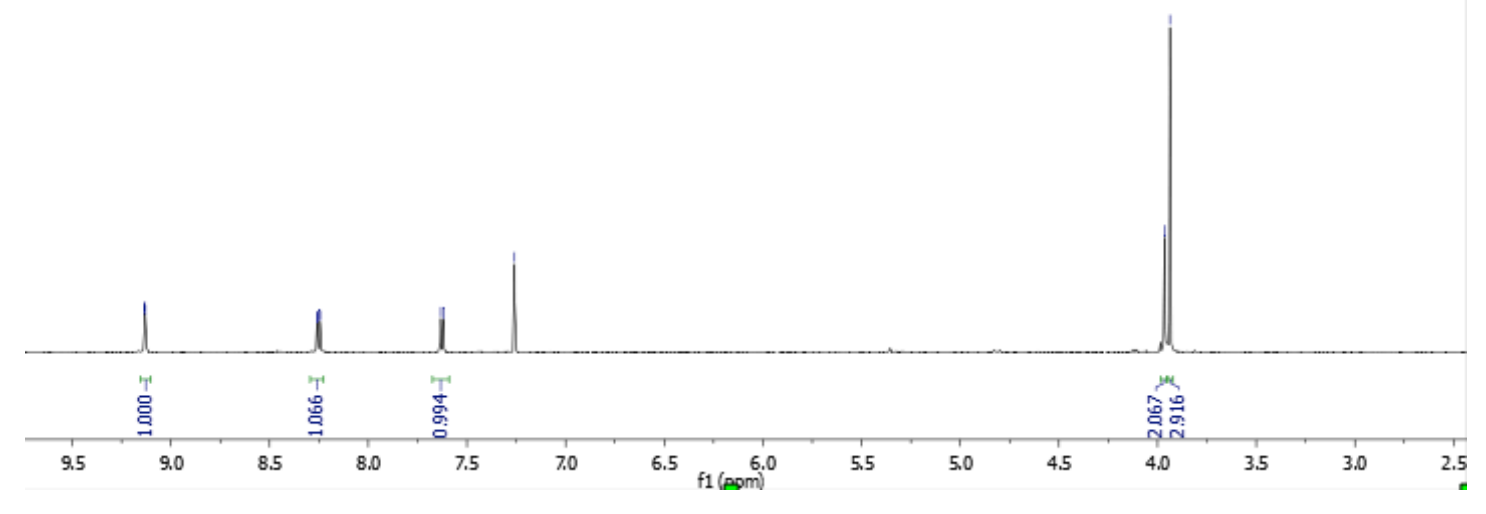

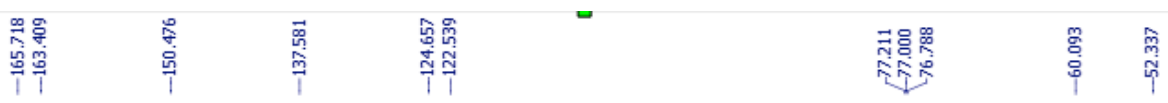

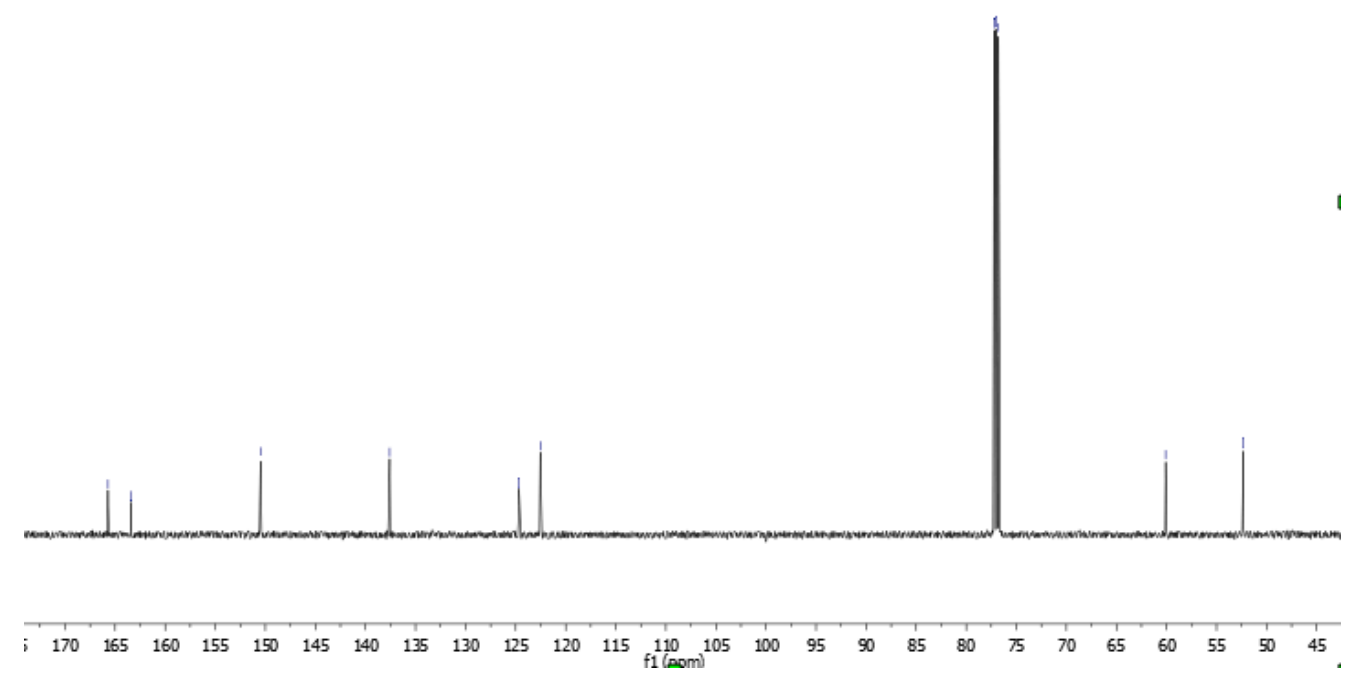



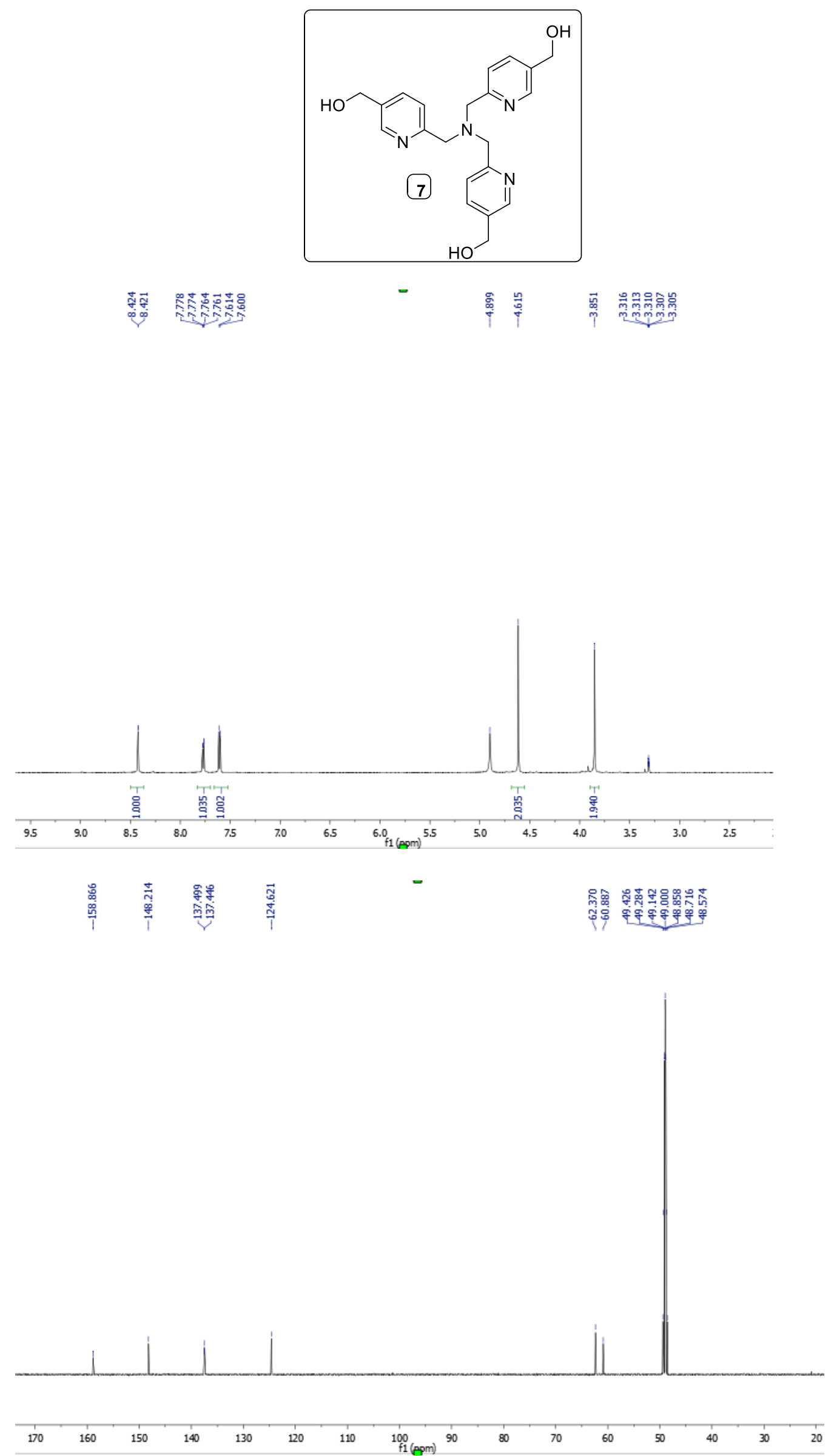

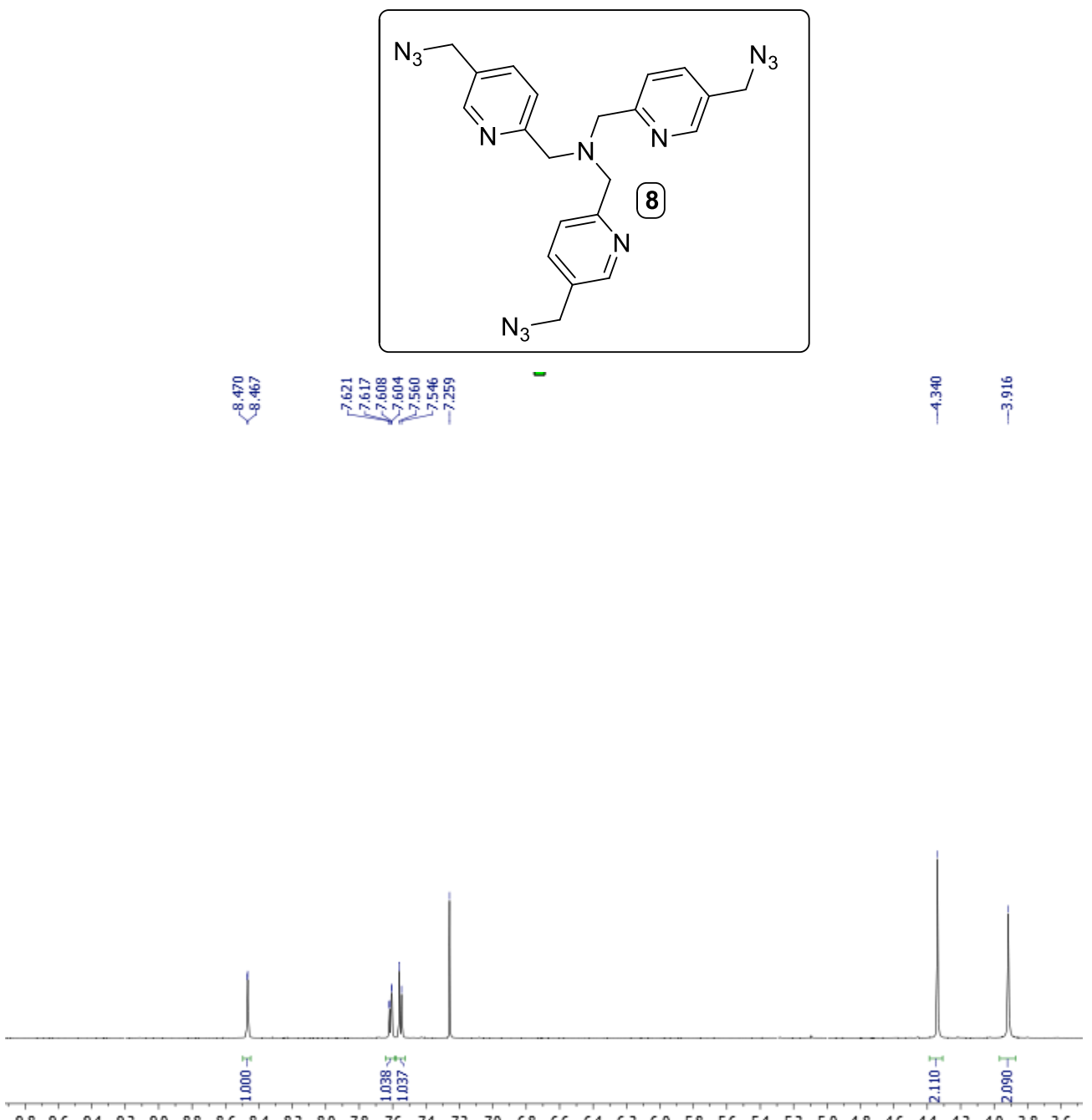

$\begin{array}{lllllllllllllllllllllllllllllllllllll}9.8 & 9.6 & 9.4 & 9.2 & 9.0 & 8.8 & 8.6 & 8.4 & 8.2 & 8.0 & 7.8 & 7.6 & 7.4 & 7.2 & 7.0 & 6.8 & 6.6 & 6.4 & 6.2 & 6.0 & 5.8 & 5.6 & 5.4 & 5.2 & 5.0 & 4.8 & 4.6 & 4.4 & 4.2 & 4.0 & 3.8 & 3.6\end{array}$

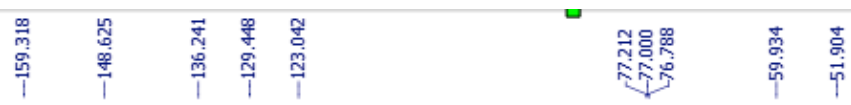

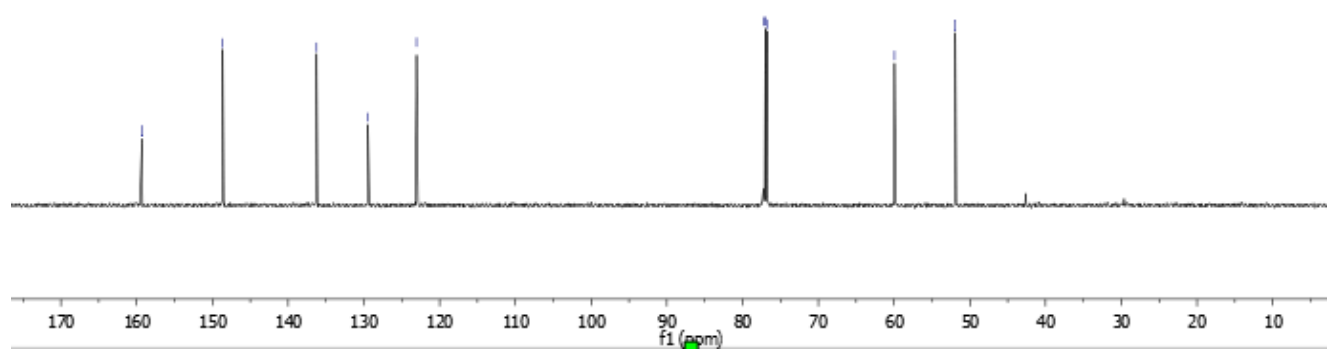




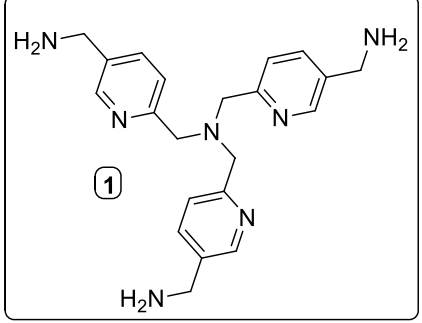

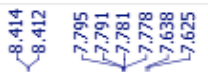

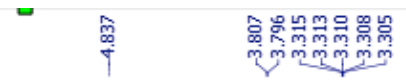

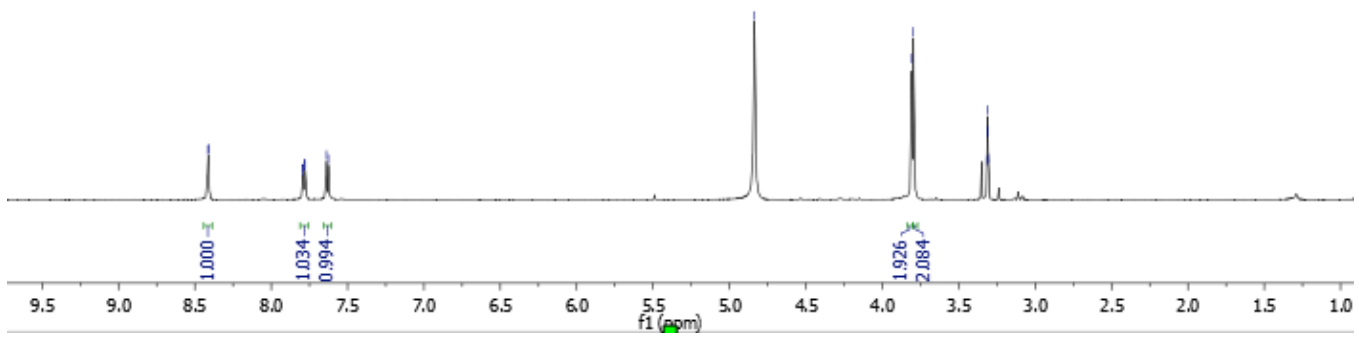

I

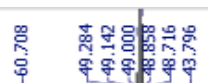

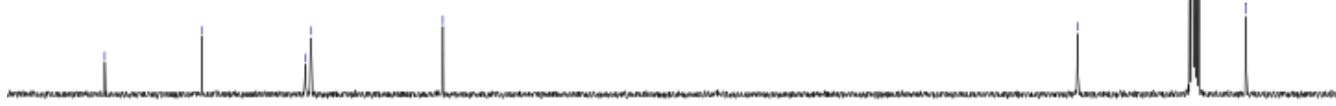

$\begin{array}{llllllllllllllllllllllllllllll}165 & 160 & 155 & 150 & 145 & 140 & 135 & 130 & 125 & 120 & 115 & 110 & 105 & 100 & 95 & 90 & 85 & 80 & 75 & 70 & 65 & 60 & 55 & 50 & 45 & 40 & 35\end{array}$ 


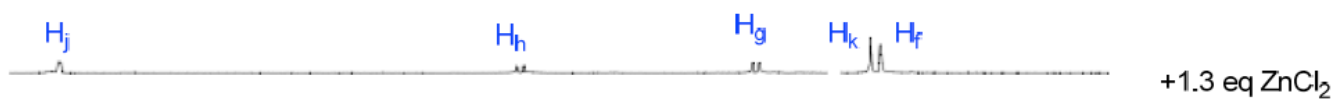
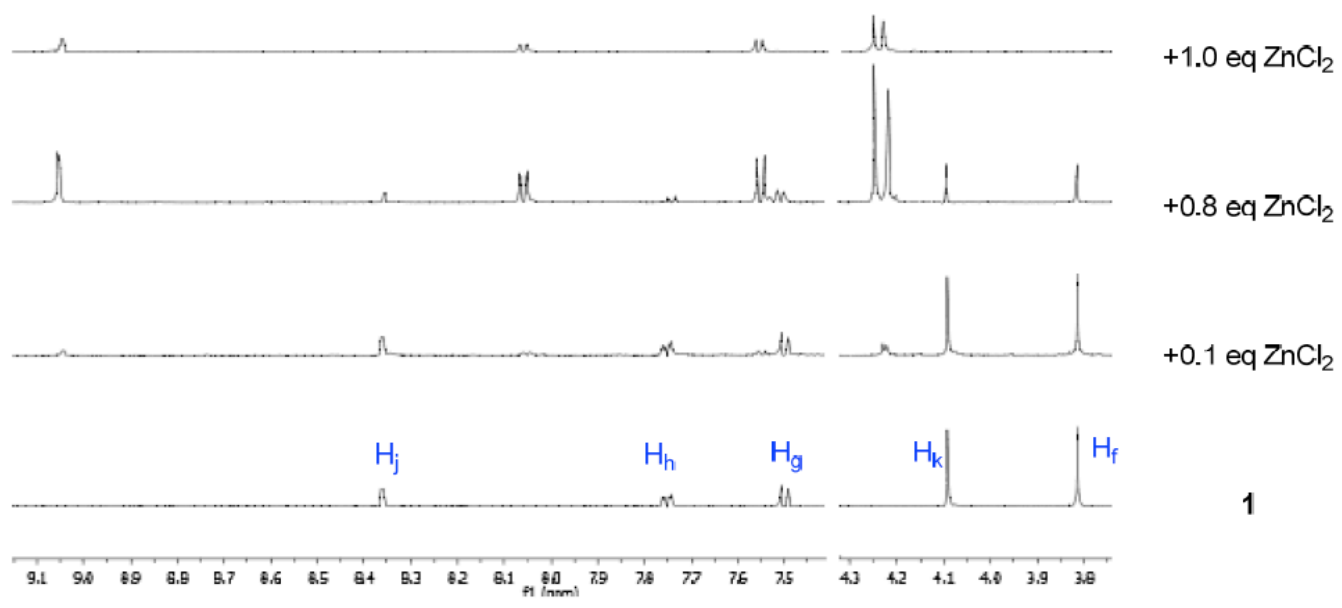

1

Figure S1. ${ }^{1} \mathrm{H}$ NMR spectra $(600 \mathrm{MHz}, 298 \mathrm{~K})$ of a solution of $\mathbf{1}(0.2 \mathrm{mM}$ in $10 \mathrm{mM}$ phosphate buffer at $\mathrm{pH}=7.2)$ obtained upon an incremental addition of $\mathrm{ZnCl}_{2}(30 \mathrm{mM}$ in $10 \mathrm{mM}$ phosphate buffer at $\mathrm{pH}$ $=7.2$ ). 

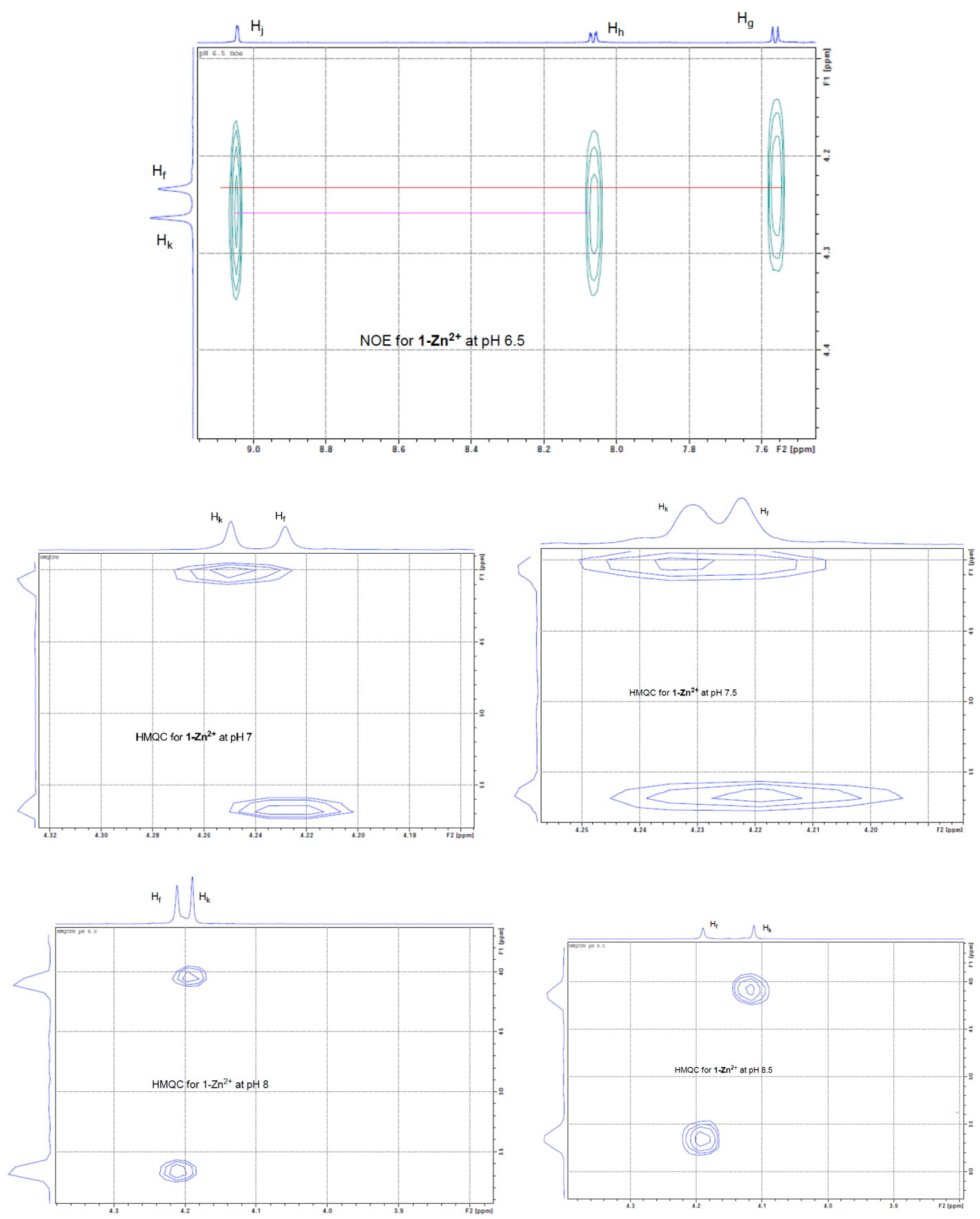

Figure S2. (Top) A segment of ${ }^{1} \mathrm{H}^{-1} \mathrm{H}$ NOESY spectrum $(600 \mathrm{MHz}, 298 \mathrm{~K})$ of $\mathbf{1 - Z n}$ (II) $(0.5 \mathrm{mM})$ in $10 \mathrm{mM}$ phosphate buffer at $\mathrm{pH}=6.5$, showing the magnetization transfer of $\mathbf{H}_{\mathrm{k}} / \mathbf{H}_{\mathrm{j} / \mathrm{h}}$ and $\mathbf{H}_{\mathrm{f}} / \mathbf{H}_{\mathrm{g}}$ to permit an unambiguous assignment of these resonances. (Below) ${ }^{1} \mathrm{H}-{ }^{13} \mathrm{C}$ HMQC spectra $(600 \mathrm{MHz}$, $298 \mathrm{~K})$ of $\mathbf{1 - Z n}(\mathrm{II})(0.5 \mathrm{mM})$ in $10 \mathrm{mM}$ phosphate buffer at $\mathrm{pH}=7-8.5$ showing cross correlations between $\mathbf{H}_{\mathrm{k}}$ and ${ }^{13} \mathbf{C}_{\mathrm{k}}$ (at a higher field) and $\mathbf{H}_{\mathrm{f}}$ and ${ }^{13} \mathbf{C}_{\mathrm{f}}$ (at a lower field). 

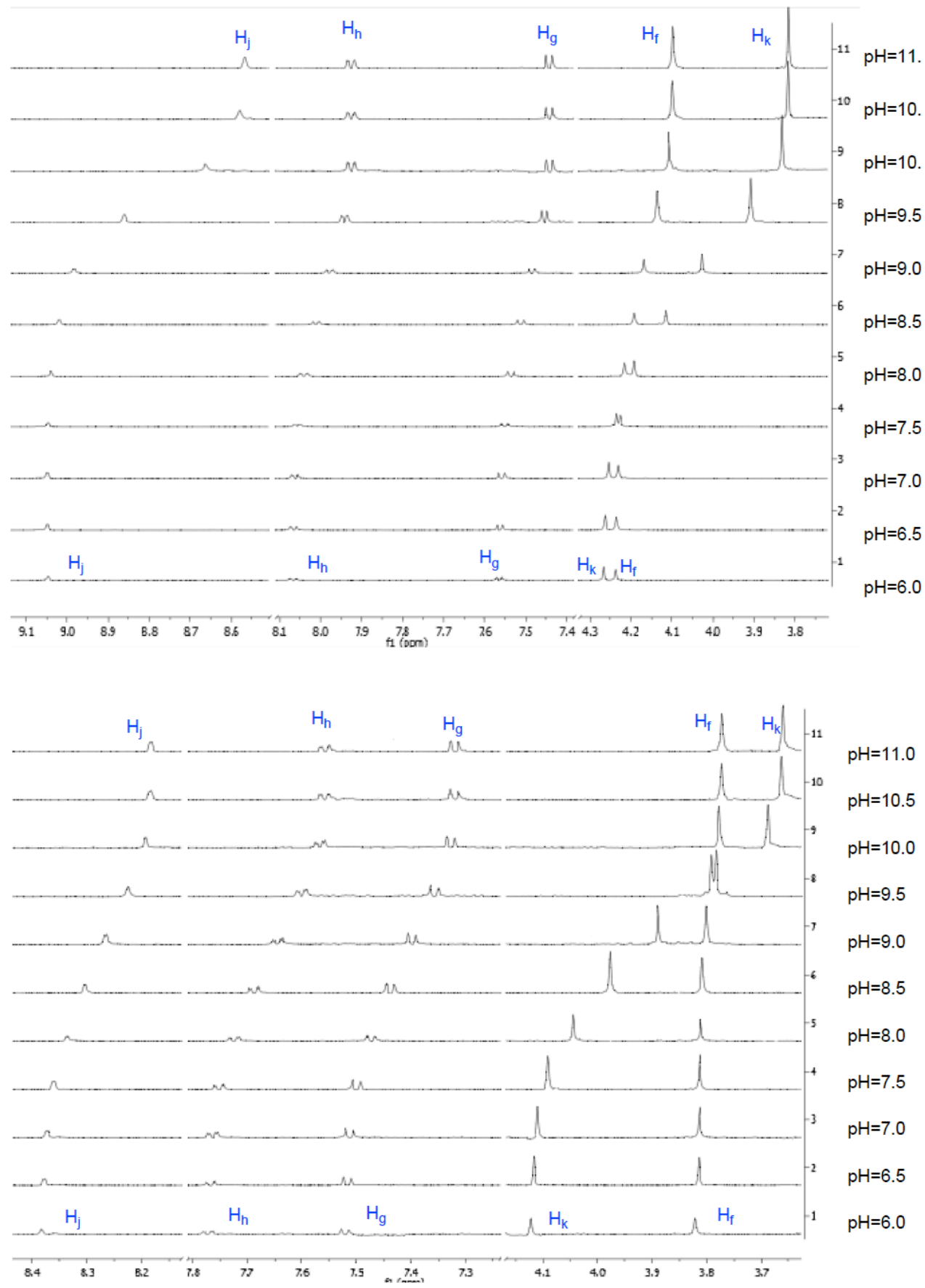

Figure S3. (Top) ${ }^{1} \mathrm{H}-\mathrm{NMR}$ spectra $(600 \mathrm{MHz}, 298 \mathrm{~K})$ of $\mathbf{1 - Z n ( I I ) ~}(0.5 \mathrm{mM} \mathrm{mM})$ in $10 \mathrm{mM}$ phosphate buffer solutions at $\mathrm{pH}=6.0-11.0$. (Bottom). ${ }^{1} \mathrm{H}-\mathrm{NMR}$ spectra $(600 \mathrm{MHz}, 298 \mathrm{~K})$ of $1(0.5 \mathrm{mM})$ in 10 $\mathrm{mM}$ phosphate buffer solutions at $\mathrm{pH}=6.0-11.0$. 


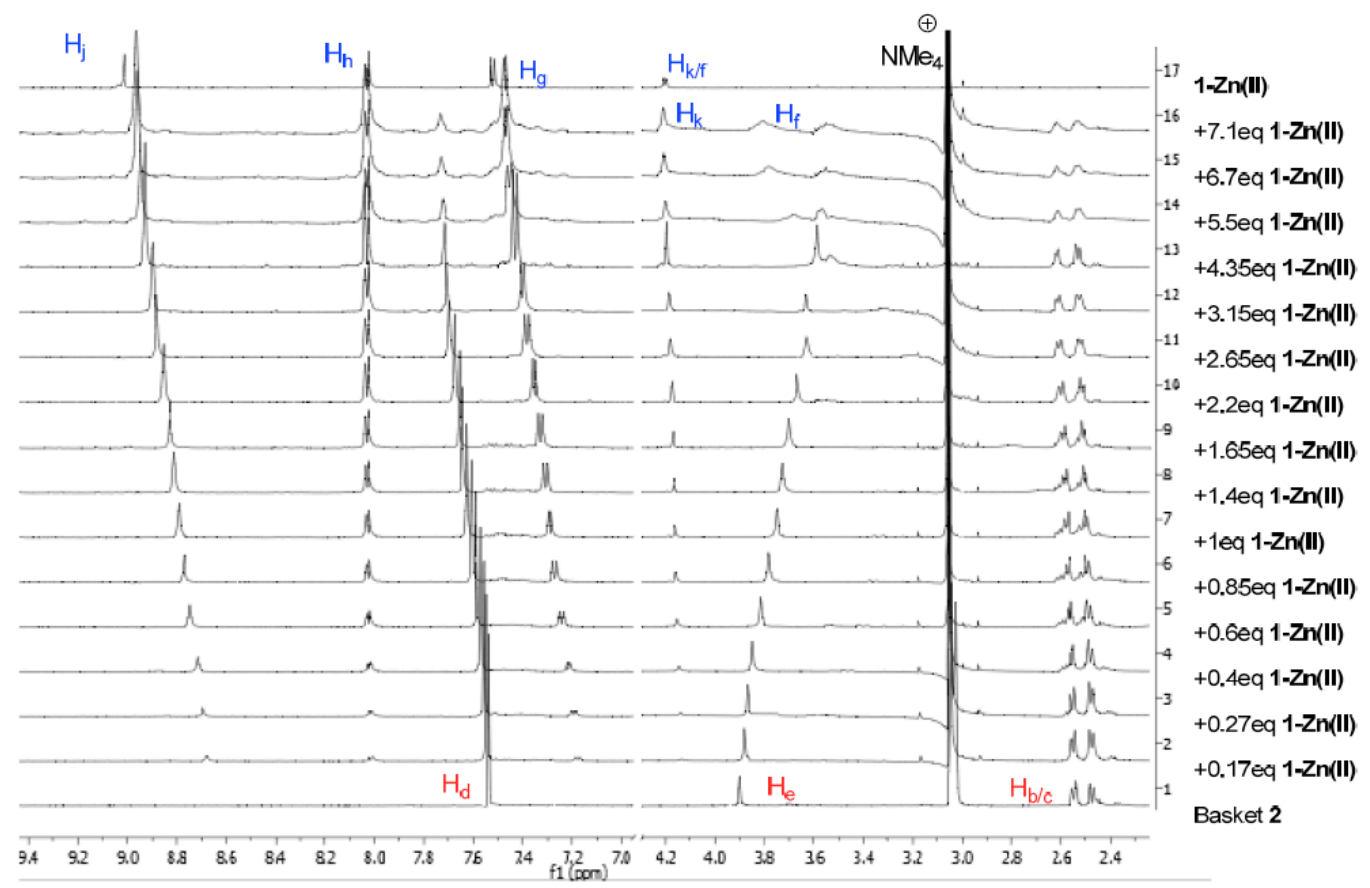

Figure S4. (A) ${ }^{1} \mathrm{H}-\mathrm{NMR}$ spectra $(600 \mathrm{MHz}, 298 \mathrm{~K})$ of basket $2(0.31 \mathrm{mM})$ dissolved in $10 \mathrm{mM}$ phosphate buffer at $\mathrm{pH}=7.2$ and obtained after incremental addition of a standard solution of 1-Zn(II) $(8.5 \mathrm{mM})$; the standard solution was obtained upon dissolving $\mathbf{1}$ in phosphate buffer at $\mathrm{pH}=7.2$ followed by one molar equivalent of $\mathrm{ZnCl}_{2}$ and three equivalents of concentrated $\mathrm{HCl}$. 

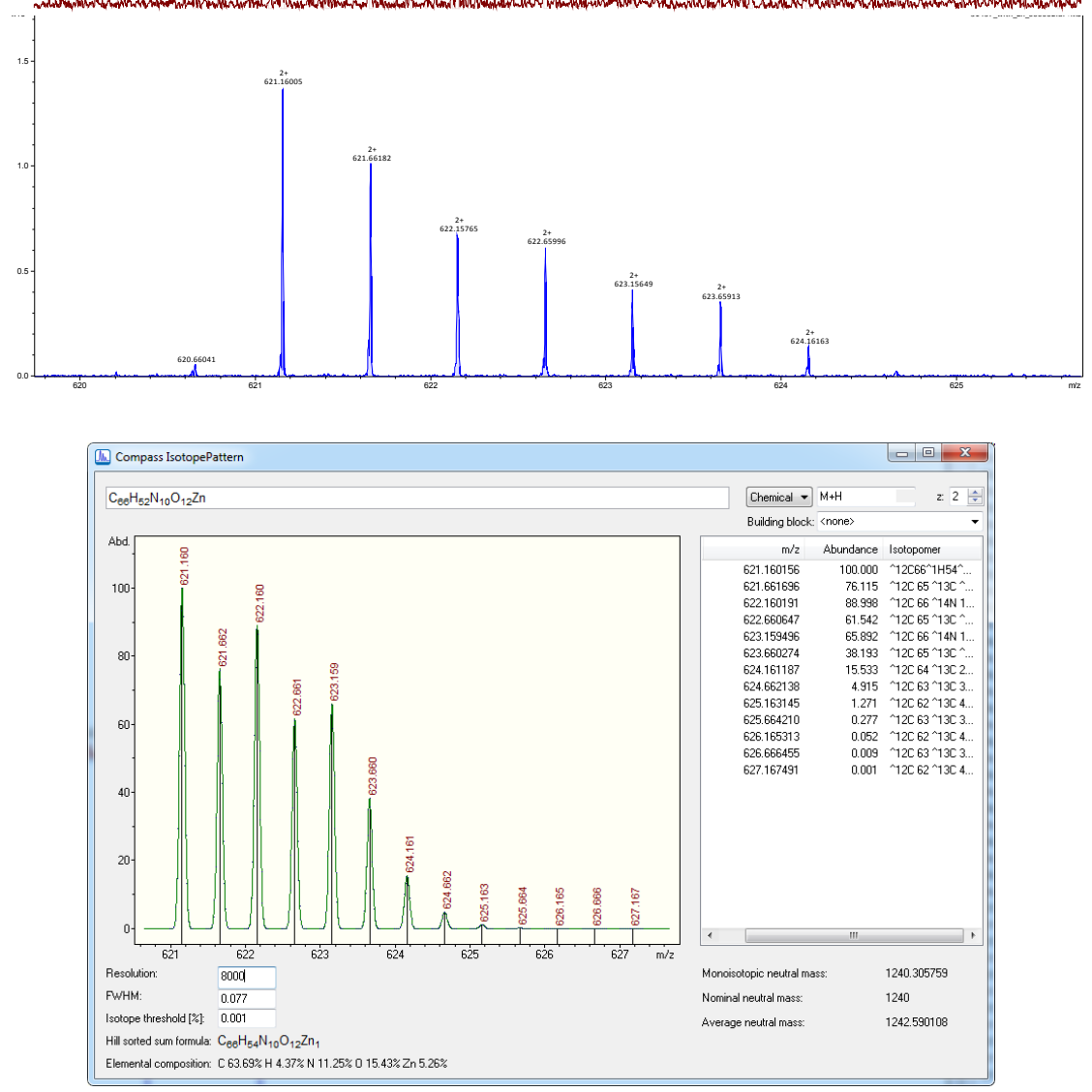

Figure S5. (Top) A segment of electrospray ionization (ESI) spectrum of 1- $\mathrm{Zn}$ (II) dissolved in $\mathrm{H}_{2} \mathrm{O}$ $(0.1 \mathrm{mM})$ and containing basket $2(0.1 \mathrm{mM})$ : the observed signals correspond to doubly charged ion of 1-ZnC2 complex at 621.160 a.u. (Bottom) Computer simulated isotope distribution of doubly charged 1-ZnC2 of the composition $\mathrm{C}_{66} \mathrm{H}_{52} \mathrm{~N}_{10} \mathrm{O}_{12} \mathrm{Zn}$.

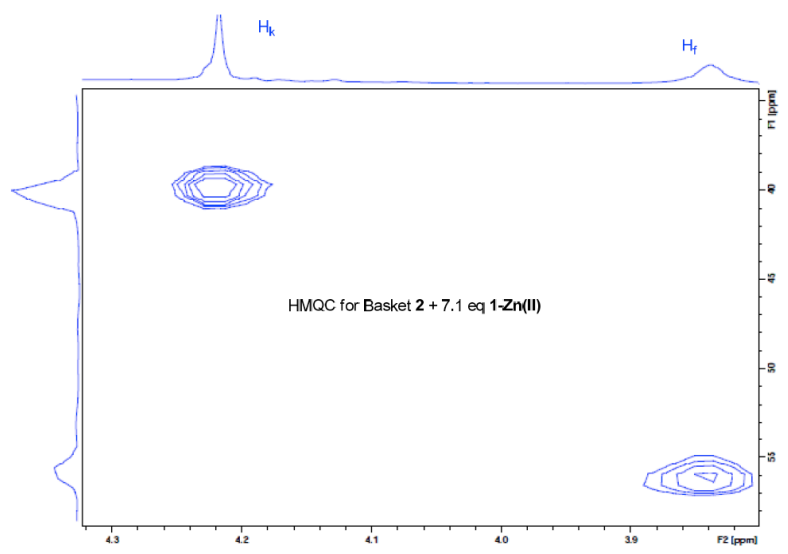

Figure S6. A segment of ${ }^{1} \mathrm{H}-{ }^{13} \mathrm{C}$ HMQC spectrum $(600 \mathrm{MHz}, 298 \mathrm{~K})$ of basket $2(0.31 \mathrm{mM})$ containing $\mathbf{1 - Z n}$ (II) $(2.2 \mathrm{mM})$ in phosphate buffer at $\mathrm{pH}=7.2$. The apparent cross correlations between $\mathbf{H}_{\mathrm{k}}$ and ${ }^{13} \mathbf{C}_{\mathrm{k}}$ (at a higher field) as well as $\mathbf{H}_{\mathrm{f}}$ and ${ }^{13} \mathbf{C}_{\mathrm{f}}$ (at a lower field) permit the assignment of the proton resonances. 

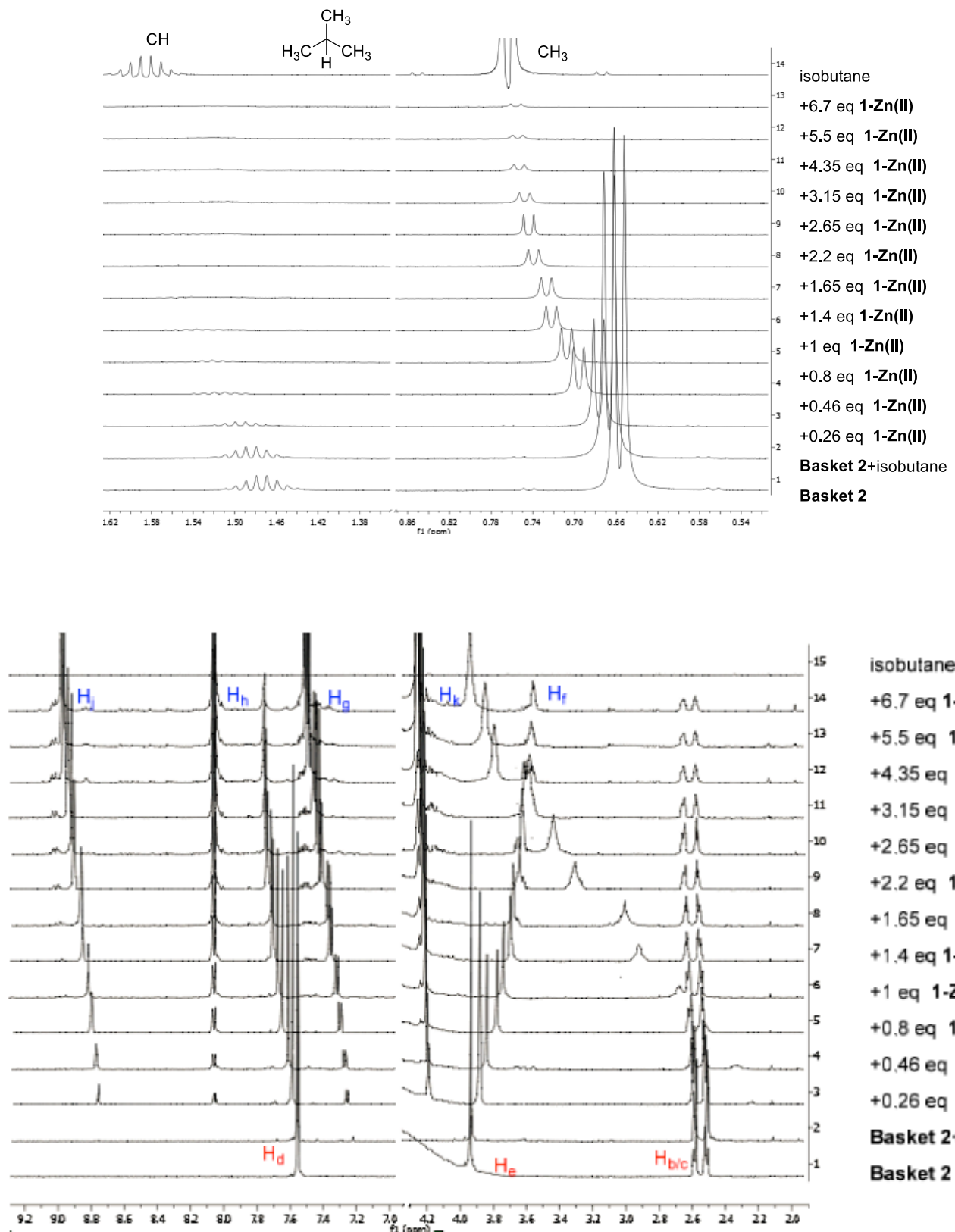

isobutane

+6.7 eq 1-Zn(II)

+5.5 eq $1-\mathrm{Zn}$ (II)

$+4,35$ eq $1-\mathrm{Zn}$ (II)

+3.15 eq $1-Z n$ (II)

+2.65 eq 1-Zn(II)

+2.2 eq 1-Zn(II)

+1.65 eq 1-Zn(II)

+1.4 eq $1-\mathrm{Zn}$ (II)

+1 eq $1-\mathrm{Zn}$ (II)

+0.8 eq $1-\mathrm{Zn}$ (II)

+0.46 eq $1-Z n$ (II)

+0.26 eq $1-Z n$ (II)

Basket 2+isobutane

Basket 2

Figure S7. An incremental addition of a standard solution of $1-\mathrm{Zn}$ (II) $(13.5 \mathrm{mM})$ to iso- $\mathrm{C}_{4} \mathrm{H}_{10}(0.8$ $\mathrm{mM})$ and basket $2(0.47 \mathrm{mM})$ in $10 \mathrm{mM}$ phosphate buffer at $\mathrm{pH}=7.2$ was monitored with ${ }^{1} \mathrm{H}$ NMR spectroscopy (700 MHz, $298.0 \mathrm{~K}$ ); the standard solution was obtained upon dissolving 1 in phosphate buffer at $\mathrm{pH}=7.2$ followed by one molar equivalent of $\mathrm{ZnCl}_{2}$ and three equivalents of concentrated $\mathrm{HCl}$. 

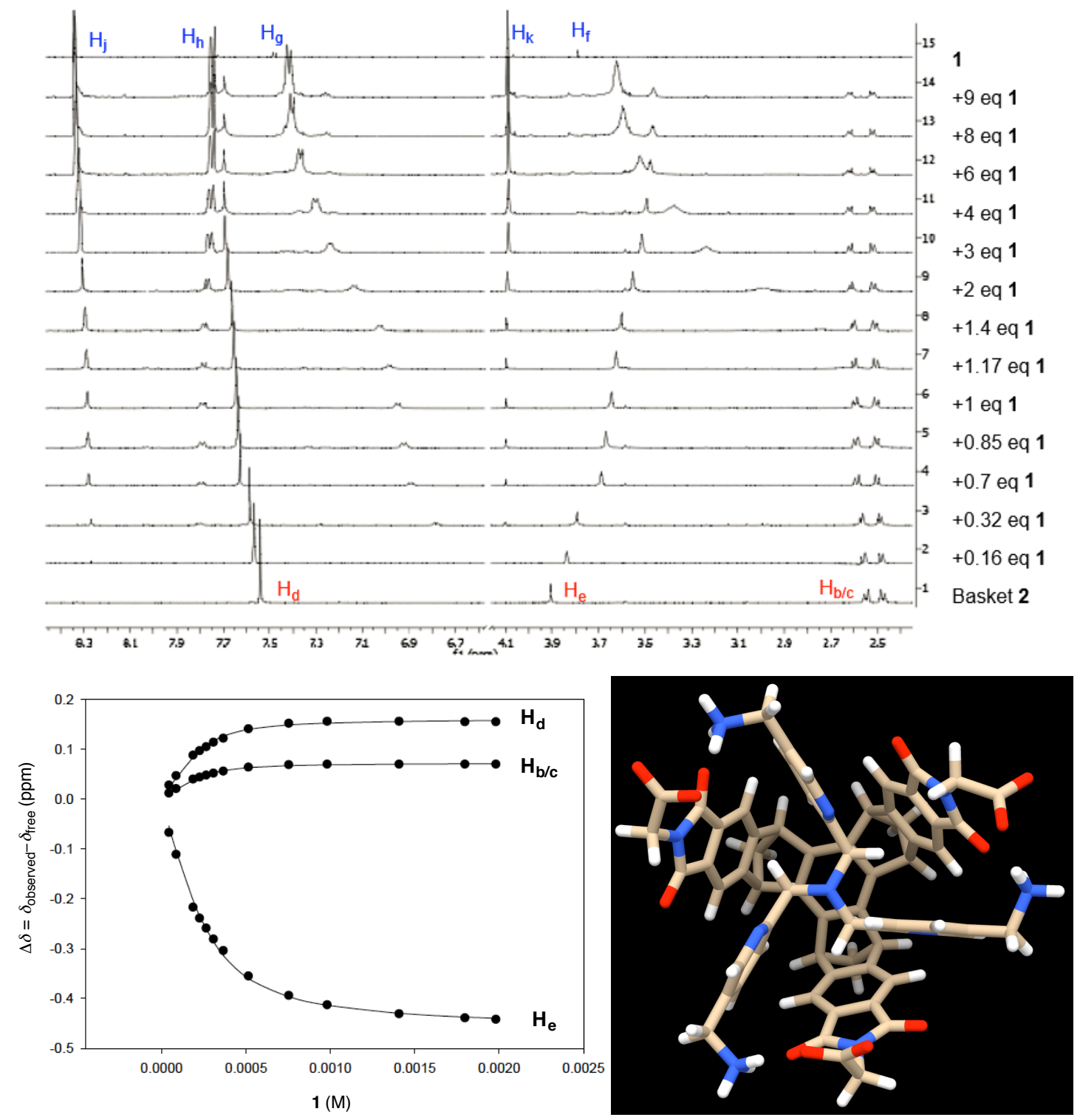

Figure S8. (Top) ${ }^{1} \mathrm{H}$ NMR spectra $(600 \mathrm{MHz}, 298.0 \mathrm{~K})$ of a solution of basket $2(0.236 \mathrm{mM}$ in $10 \mathrm{mM}$ phosphate buffer at $\mathrm{pH}=7.2$ ) obtained upon an incremental addition of standard solution of compound $\mathbf{1}(17.3 \mathrm{mM})$; the standard solution was obtained upon dissolving $\mathbf{1}$ in phosphate buffer at $\mathrm{pH}=7.2$ followed by the addition of three equivalents of concentrated $\mathrm{HCl}$. (Bottom Left) The nonlinear least-square fitting of the experimental isotherms from $\mathbf{H}_{\mathrm{b}-\mathrm{e}}$ resonances to a 1:1 stoichiometric model gave the association constants in the range of $K=1.0-2.4 \pm 0.1 \cdot 10^{4} \mathrm{M}^{-1}\left(R^{2}=0.99\right.$, Sigma Plot $)$ which on average amounts to $\Delta G^{\mathrm{o}}=5.8 \mathrm{kcal} / \mathrm{mol}$ at $298 \mathrm{~K}$. (Bottom Right) Top view of the energy-minimized structure of $\mathbf{1} \subset \mathbf{2}$ (Amber Force Field) obtained from Monte Carlo conformational search (10000 steps) in the implicit water solvent. 

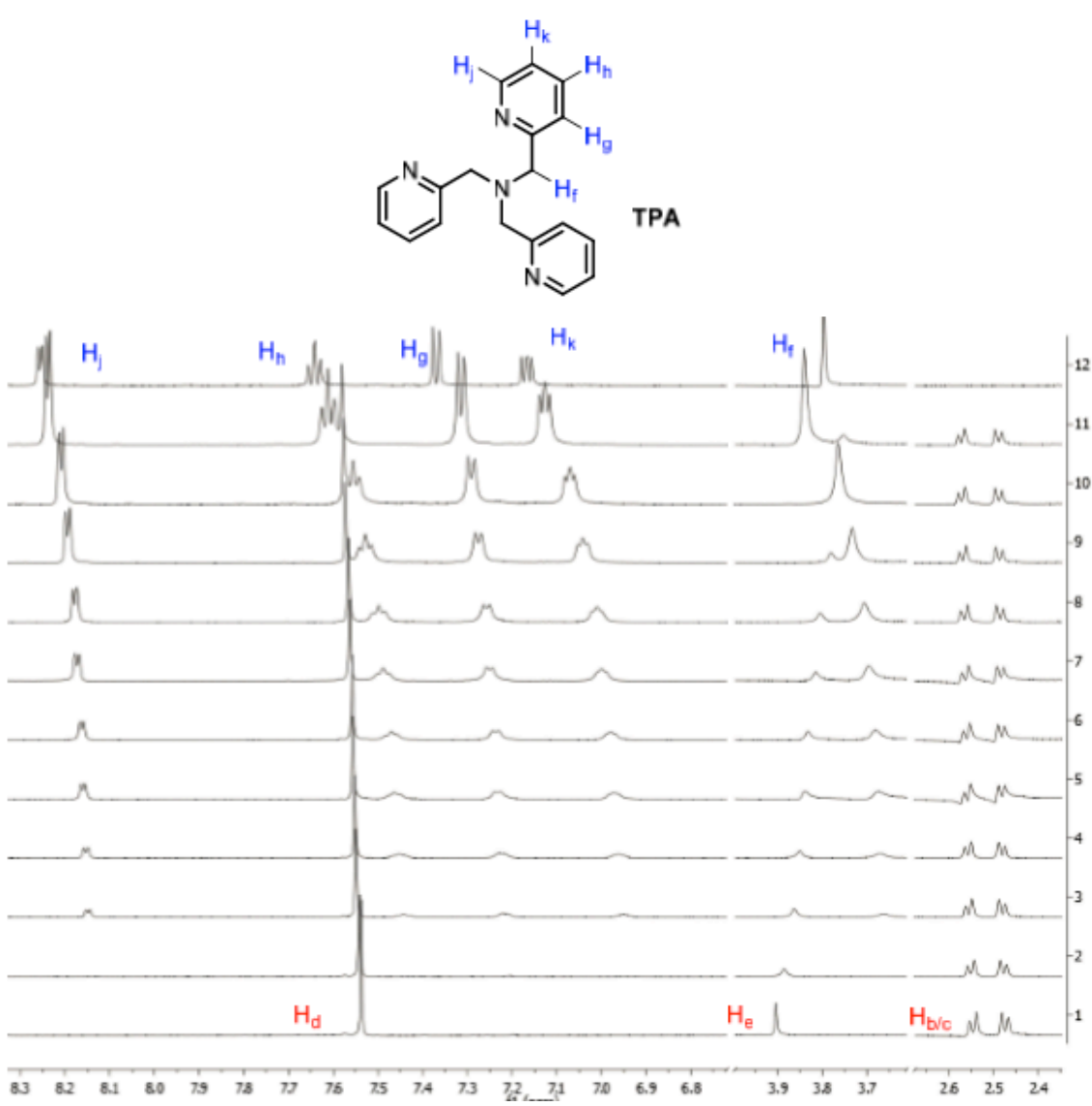

TPA

+6eq TPA

+4eq TPA

+3eq TPA

+2eq TPA

+1.5 eq TPA

+1.2 eq TPA

+1eq TPA

+0.7 eq TPA

+0.45 eq TPA

+0.15 eq TPA

Basket 2
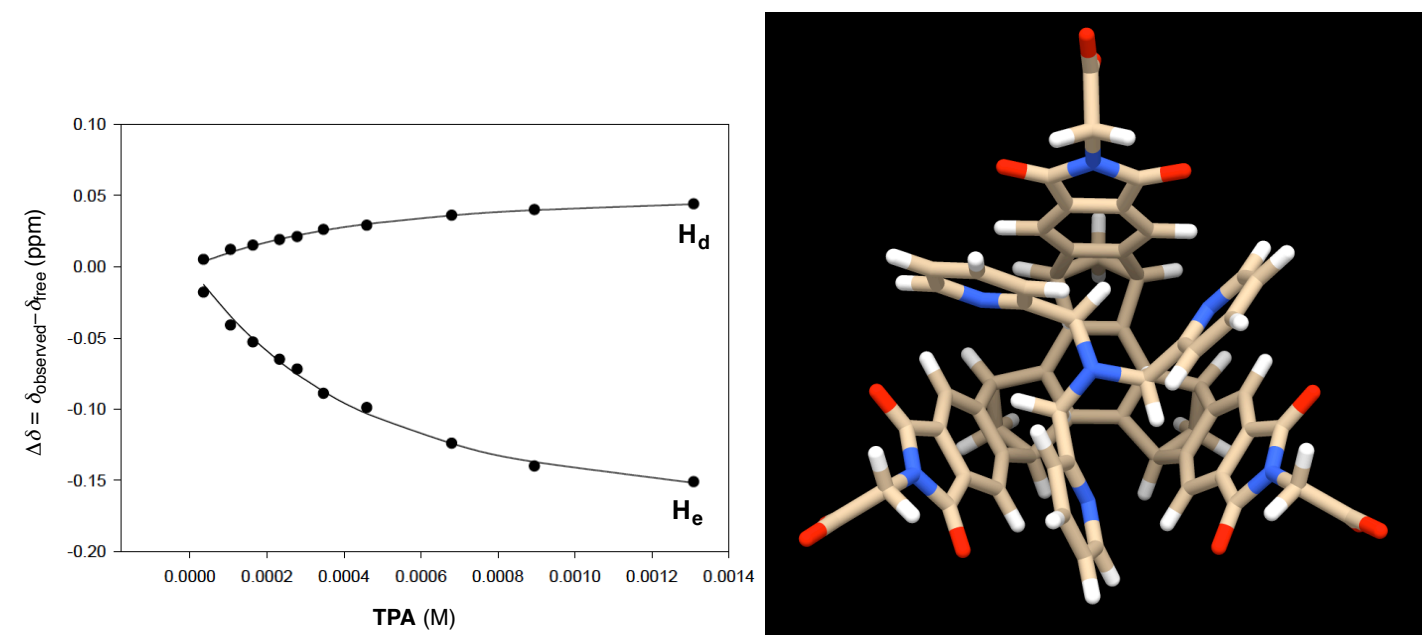

Figure S9. (Top) ${ }^{1} \mathrm{H}$ NMR spectra (600 MHz, 298.0 K) of a solution of basket $2(0.236 \mathrm{mM}$ in $10 \mathrm{mM}$ phosphate buffer at $\mathrm{pH}=7.2$ ) obtained upon an incremental addition of standard solution of unfunctionalized TPA ligand $(17.3 \mathrm{mM})$; the standard solution was obtained upon dissolving TPA in phosphate buffer at $\mathrm{pH}=7.2$ followed by the addition of three equivalents of concentrated $\mathrm{HCl}$. (Bottom Left) The nonlinear least-square fitting of the experimental isotherms from $\mathbf{H}_{\mathrm{d}-\mathrm{e}}$ resonances to a 1:1 stoichiometric model gave the association constants in the range of $K=3.6 \pm 0.2 \cdot 10^{3} \mathrm{M}^{-1}\left(R^{2}=\right.$ 0.99, Sigma Plot) which amounts to $\Delta G^{\mathrm{o}}=4.9 \mathrm{kcal} / \mathrm{mol}$ at $298 \mathrm{~K}$. (Bottom Right) Top view of the energy-minimized structure of TPAC2 (Amber Force Field) obtained from Monte Carlo conformational search (10000 steps) in the implicit water solvent. 

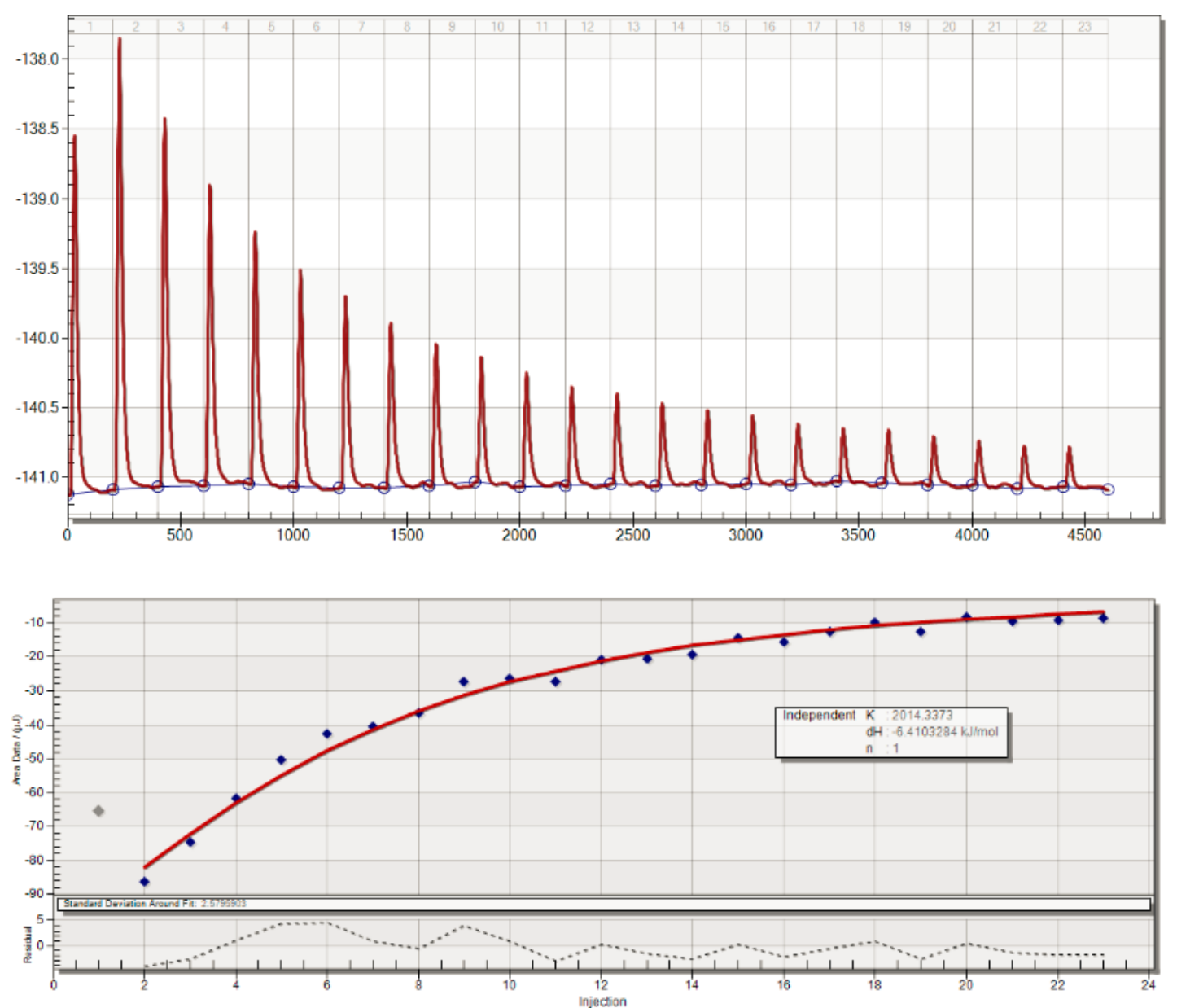

Figure S10. The experimental (top) and integrated (bottom) ITC data corresponding to incremental addition of a standard solution of TPA $(2.02 \mu \mathrm{L}$ per injection of its $15.0 \mathrm{mM}$ solution) in phosphate buffer $(30 \mathrm{mM}, \mathrm{pH}=7.2)$ to basket $2(0.5 \mathrm{mM})$ in $300.0 \mu \mathrm{L}$ of PBS $(30 \mathrm{mM}$ at $\mathrm{pH}=7.2)$ at $298.0 \mathrm{~K}$. The nonlinear least-square analysis (bottom) of the binding data was completed with the assistance of single site-binding model (with the stoichiometric coefficient $\mathrm{n}$ fixed to 1 ) to give $K_{\mathrm{a}}=2.01 \pm 0.26 \times$ $10^{3} \mathrm{M}^{-1}$ and $\Delta H^{\mathrm{o}}=-1.53 \pm 0.08 \mathrm{kcal} / \mathrm{mol}\left(R^{2}=0.95\right)$. 

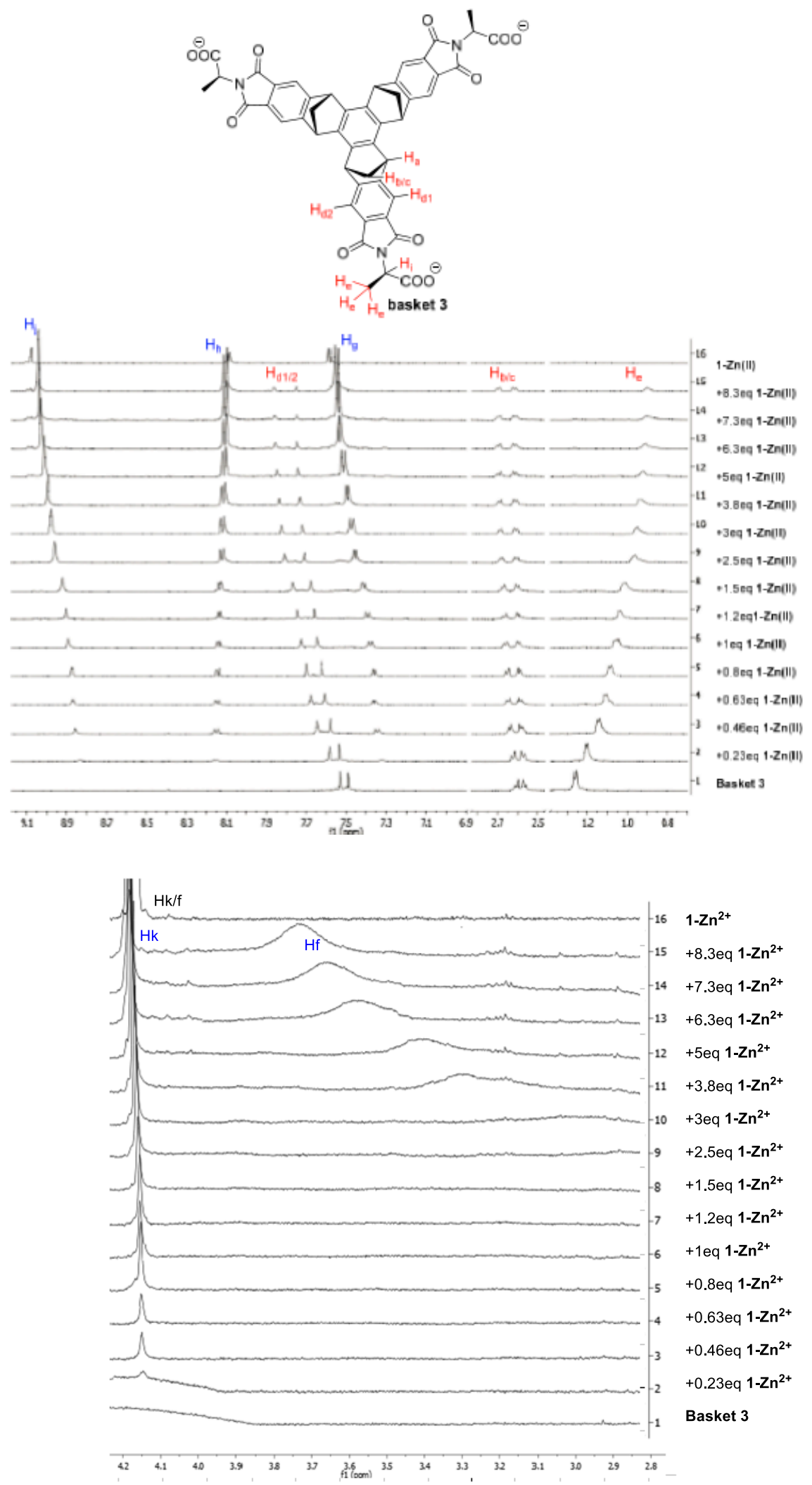

Figure S11. ${ }^{1} \mathrm{H}-\mathrm{NMR}$ spectra $(600 \mathrm{MHz}, 298 \mathrm{~K})$ of basket $3(0.31 \mathrm{mM})$ dissolved in $10 \mathrm{mM}$ phosphate buffer at $\mathrm{pH}=7.2$ obtained after incremental addition of a standard solution of $1-\mathrm{Zn}$ (II) $(8.5 \mathrm{mM})$; the standard solution was obtained upon dissolving 1 in phosphate buffer at $\mathrm{pH}=7.2$ followed by one molar equivalent of $\mathrm{ZnCl}_{2}$ and three equivalents of concentrated $\mathrm{HCl}$. 


\section{References}

(1) Liu, P.; Chen, Y.; Deng, J.; Tu, Y. Synthesis 2001, 2001, 2078.

(2) Tobey, S. L.; Anslyn, E. V. Journal of the American Chemical Society 2003, 125, 14807.

(3) Soai, K.; Oyamada, H.; Ookawa, A. Synthetic Communications 1982, 12, 463.

(4) Dutta, S.; Li, Y.-L.; Rock, W.; Houtman, J. C. D.; Kohen, A.; Cheatum, C. M. The Journal of Physical Chemistry B 2012, 116, 542.

(5) Boldog, I.; Muñoz-Lara, F. J.; Gaspar, A. B.; Muñoz, M. C.; Seredyuk, M.; Real, J. A. Inorganic Chemistry 2009, 48, 3710. 